\title{
Reduction of Adherence of $E$. coli O157:H7 to HEp-2 Cells and to Bovine Large Intestinal Mucosal Explants by Colicinogenic E. coli
}

\author{
A. I. Etcheverría, ${ }^{1}$ G. H. Arroyo, ${ }^{1}$ R. Alzola, ${ }^{2}$ and A. E. Parma ${ }^{1}$ \\ ${ }^{1}$ Laboratorio de Inmunoquímica y Biotecnología, Departamento de Sanidad Animal y Medicina Preventiva, Facultad de Ciencias \\ Veterinarias, Universidad Nacional del Centro Provincia de Buenos Aires, Pinto 399 (7000), Tandil, Argentina \\ ${ }^{2}$ Laboratorio de Histología, Departamento de Ciencias Biológicas, Facultad de Ciencias Veterinarias, Universidad Nacional del Centro \\ Provincia de Buenos Aires, Pinto 399 (7000), Tandil, Argentina
}

Correspondence should be addressed to A. I. Etcheverría, analiain@vet.unicen.edu.ar

Received 9 August 2011; Accepted 20 September 2011

Academic Editors: H.-P. Horz and J. D. Stopforth

Copyright ( $) 2011$ A. I. Etcheverría et al. This is an open access article distributed under the Creative Commons Attribution License, which permits unrestricted use, distribution, and reproduction in any medium, provided the original work is properly cited.

Enterohemorrhagic E. coli strains (EHEC) had emerged as foodborne pathogens and cause in human diarrhea and hemolyticuremic syndrome. Because of the widespread distribution of EHEC serotypes and O157 and non-O157 in cattle population, its control will require interventions at the farm level such as the administration of probiotics that produce inhibitory metabolites. E. coli O157:H7 shows tissue tropisms for the gastrointestinal tract (GIT) of cattle. The aim of this study was to test the ability of a colicinogenic E. coli (isolated from bovine) to reduce the adherence of E. coli O157:H7 to HEp-2 cells and to GIT of cattle. We inoculated HEp-2 cells and bovine colon explants with both kinds of strains. Colicinogenic E. coli was able to reduce the adherence of E. coli $\mathrm{O} 157: \mathrm{H} 7$ to HEp-2 cells and to bovine tissues.

\section{Introduction}

Enterohemorrhagic E. coli strains (EHEC) are a subset of Shiga toxin-producing E. coli (STEC) that had emerged as foodborne pathogens [1-3]. Human illnesses caused by EHEC range from watery diarrhea or hemorrhagic colitis to the hemolytic-uremic syndrome or thrombotic thrombocytopenic purpura [4]. The predominant EHEC serotype associated with the most severe disease is $\mathrm{O} 157: \mathrm{H} 7[2,5]$. Various studies confirmed that cattle are the main reservoir of STEC [6-15].

The persistence of E. coli O157:H7 in cattle may be due to the ability of the bacteria to colonize a particular location within the gastrointestinal tract (GIT). Several authors have reported that E. coli O157:H7 shows tissue tropisms for the colon, lymphoid follicle-dense mucosa at the terminal rectum, and the rectoanal junction [16-18]. E. coli O157:H7 intimately attaches to a variety of cell types and tissues, and a few studies have demonstrated that it can form attaching and effacing lesions on explants of bovine intestinal tissues $[19,20]$.

Because of the widespread distribution of EHEC serotypes, O157, and non-O157, in cattle population, its control will require interventions at the farm level [21]. A promising method for the control of foodborne pathogens in livestock is the feeding of beneficial bacteria, often referred to as probiotics [22]. Probiotics can interfere with pathogenic strains by producing metabolites that are inhibitory to E. coli O157:H7. Some strains of $E$. coli can produce colicins that are inhibitory in vitro to diarrheagenic $E$. coli strains, including O157:H7 [23]. Several authors have identified bacteria with potential ability to exclude E. coli O157:H7 from the GIT of cattle [23-25]. In a previous study, we isolated strains of colicinogenic E. coli from bovine colon which have the ability to inhibit the growth of $E$. coli $\mathrm{O} 157: \mathrm{H} 7$ in vitro [26]. Taking into account this fact, the aim of this study was to test the ability of colicinogenic $E$. coli to interfere with 
the adherence of E. coli O157:H7 to HEp-2 cells and to bovine colonic explants.

\section{Materials and Methods}

2.1. Bacterial Strains. A strain of Escherichia coli O157:H7 $\left(s_{x_{2}}\right.$, eae, ehxA) isolated from grazing cattle and a colicinogenic E. coli with anti-O157 activity isolated previously by us [26] were used to prepare the inocula. Colicinogenic E. coli used in this study was selected taking into account the size of the inhibition zone and the inhibitory activity against different E. coli serotypes (O20:H19; O25:H19; O91:H21; O113:H21; O117:H7; O145:H-; O171:H2; O174:H21; $\mathrm{O} 175: \mathrm{H} 8$ ) isolated in our laboratory in previous work. E. coli $\mathrm{O} 157: \mathrm{H} 7$ was selected based onto its virulence genotype, which is the frequently found in HUS-producing O157:H7 isolates. Cultures of both strains were grown overnight on Luria Bertani broth (LB), with shaking $(200 \mathrm{rpm})$ at $37^{\circ} \mathrm{C}$. The cultures were washed twice with phosphate-buffered saline and adjusted at a concentration of $2 \times 10^{7} \mathrm{cfu} \mathrm{mL}^{-1}$. Both strains were resistant to nalidixic acid $\left(50 \mu \mathrm{g} \mathrm{mL}^{-1}\right)$.

2.2. Culture of HEp-2 Cells. The cell line was kindly provided by INTA Castelar. Cells were cultured in Minimal Essential Medium (MEM 0643 Sigma) added with 10\% of fetal calf serum (Internegocios S.A.) at $37^{\circ} \mathrm{C}$ with $5 \% \mathrm{CO}_{2}$.

2.3. Inoculation of HEp-2 Cells. For the adherence assays, we used 24 well tissue culture plates (Corning 25820).

The supernatant was discarded and plates were washed three times with phosphate-buffered saline (PBS), then it was added fresh medium in each well.

For inoculating the cells, E. coli O157:H7 was cultured in Luria Bertani broth at $37^{\circ} \mathrm{C}$ for $18 \mathrm{~h}$ with shaking, the culture was adjusted by $\mathrm{OD}_{600}$ to a concentration of $10^{5} \mathrm{cfu}$ $\mathrm{mL}^{-1}$, and the culture of colicinogenic E. coli was adjusted to two different concentrations $\left(10^{5}\right.$ and $\left.10^{6} \mathrm{cfu} \mathrm{mL}^{-1}\right)$. We inoculated $100 \mu \mathrm{L}$ of the suspension of $E$. coli $\mathrm{O} 157: \mathrm{H} 7$ alone, $100 \mu \mathrm{l}$ of each colicinogenic E. coli suspension alone, and two different mixtures: (i) E. coli O157:H7 $\left(10^{5} \mathrm{cfu} \mathrm{mL}^{-1}, 100 \mu \mathrm{L}\right)$ plus colicinogenic E. coli $\left(10^{5} \mathrm{cfu} \mathrm{mL}^{-1}, 100 \mu \mathrm{L}\right)$ and (ii) $E$. coli O157:H7 $\left(10^{5} \mathrm{cfu} \mathrm{mL}^{-1}, 100 \mu \mathrm{L}\right)$ plus colicinogenic E. coli $\left(10^{6} \mathrm{cfu} \mathrm{mL} \mathrm{m}^{-1}, 100 \mu \mathrm{L}\right)$.

Plates were incubated at $37^{\circ} \mathrm{C}$ in $5 \% \mathrm{CO}_{2}$ during $3 \mathrm{~h}$, the monolayer was washed three times with PBS, and $100 \mu \mathrm{L}$ per well of Trypsine-EDTA was added. The supernatants with the cell disattached were recovered to be seeded onto agar plates. Several dilutions of the cell suspensions were seeded onto MacConkey Sorbitol agar plates supplemented with $50 \mu \mathrm{g} \mu \mathrm{L}^{-1}$ nalidixic acid (SMAC-NAL plates) to quantify sorbitol-negative and sorbitol-positive colonies corresponding to E. coli $\mathrm{O} 157$ and colicinogenic E. coli, respectively.

The experiments were performed in triplicate.

2.4. Collection of Explants. Sections of $10 \mathrm{~cm}$ of bovine colon were obtained at slaughter immediately after killing. Tissues were washed with Minimal Essential Medium (MEM
0643) and transported to the laboratory on ice. Prior to the inoculation, fat was removed and tissues were opened along the mesenteric border and placed in cold MEM. The tissues were washed 3 times for a period of $10 \mathrm{~min}$ each. Then, they were washed with $0.9 \% \mathrm{NaCl}$ during $30 \mathrm{~min}$ with shaking. The samples were placed in MEM without antibiotics. The tissues, now referred as explants, were cut into $3 \times 5 \mathrm{~mm}$ pieces which were placed mucosal side up onto sterile sponges with two explants per sponge. They were placed in each well of 6 well tissue culture plates (Greiner Bio-One 657 160).

2.5. Inoculation of Explants. Each explant was inoculated with $25 \mu \mathrm{L}$ of bacterial suspensions containing $2 \times 10^{7} \mathrm{cfu}$. One explant was inoculated with E. coli O157:H7 only, another one with colicinogenic E. coli, and the last one with E. coli O157:H7 and colicinogenic E. coli equally. We left an explant without inoculating as negative control. The explants were incubated in MEM for $6 \mathrm{~h}$ at $37^{\circ} \mathrm{C}$ in $5 \%$ $\mathrm{CO}_{2}$ atmosphere on a rocker. MEM was added until it just reached the base of the explants. During the incubation, the medium was replaced hourly by fresh sterile one to avoid the overgrowth of bacteria and maintain constant $\mathrm{pH}$.

2.6. Processing of Explants. After the incubation, each explant was cut in half. One piece of each was processed for culture in SMAC-Nal plates, and the other was fixed in $10 \%$ neutral buffered formalin and processed for paraffin sectioning according to standard techniques. Sections from each paraffin block were stained immunohistochemically for the detection of O157:H7 adherent bacteria. These sections were firstly incubated with rabbit anti-E. coli O157 serum as the primary antibody in a $1: 200$ dilution with Triton $\mathrm{X}$-100-carrageenan (TCT). Then, a second incubation was given with goat anti-rabbit antibody for $30 \mathrm{~min}$ followed by incubation with peroxidase-antiperoxidase complex. To make the reaction visible the sections were incubated with Tris- $\mathrm{HCl}$ containing diaminobenzidine and hydrogen peroxide. The sections were observed by light microscopy.

For culture in agar plates, explants were vigorously vortexed in $1 \mathrm{~mL}$ of sterile $0.9 \% \mathrm{NaCl}$ to dislodged attached bacteria, and $100 \mu \mathrm{L}$ of these suspensions were plated onto SMAC-Nal plates and incubated for $18 \mathrm{~h}$ at $37^{\circ} \mathrm{C}$. Sorbitolnegative colonies were tested with a latex agglutination test for E. coli O157 (E. coli O157 Latex Test Kit-Oxoid). The experiments were performed in duplicate.

\section{Results}

3.1. Adherence to HEp-2 Cells. When the adherence of E. coli $\mathrm{O} 157: \mathrm{H} 7$ and colicinogenic E. coli was evaluated, it was found that depathogenic strain adhered less to HEp-2 cells than the colicinogenic E. coli (38.5\% versus $68.1 \%$ resp.) when both strains were used in equal concentrations. These differences were even higher (3.6\% for E. coli O157:H7 versus $96.4 \%$ for colicinogenic E. coli) when the concentration of the colicinogenic strain was ten-fold increased (Table 1). The 


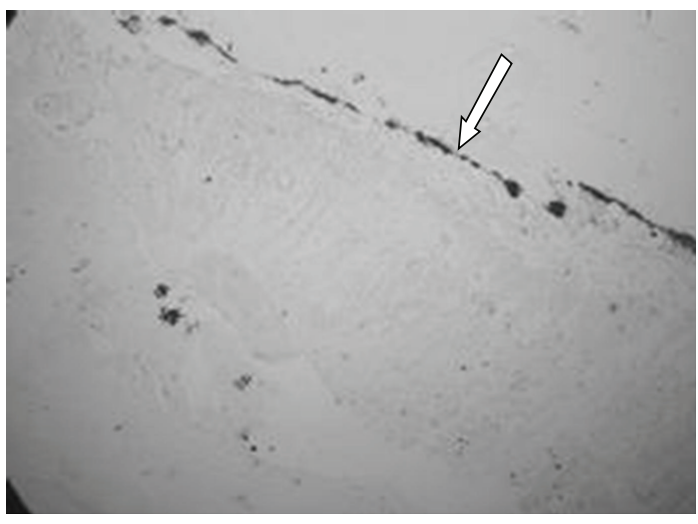

(a)

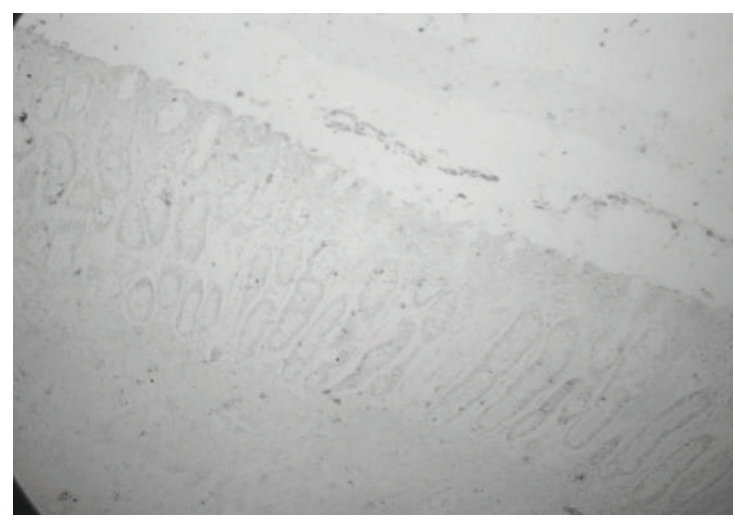

(b)

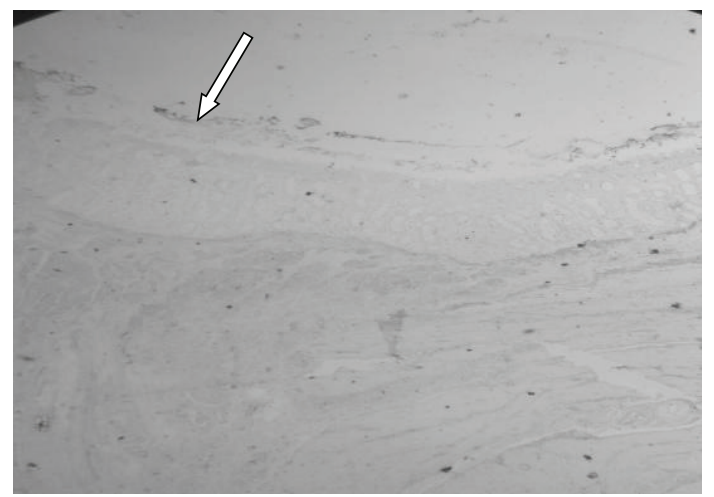

(c)

FIgURE 1: Sections of explants from bovine colon (arrows indicate E. coli O157:H7 attached). (a) Bovine colon explant inoculated with E. coli O157:H7. Bacteria attached to epithelial edge (10X), (b) bovine colon explant inoculated with colicinogenic E. coli (10X), and (c) bovine colon explant inoculated with E. coli O157:H7 and colicinogenic E. coli (4X).

TAble 1: Percentages of bacteria adhered to HEp-2 cells.

\begin{tabular}{lcc}
\hline Strains & Inoculum $\left(\mathrm{cfu} \mathrm{mL}^{-1}\right)$ & $\begin{array}{c}\text { \% of adhered and } \\
\text { recovered bacteria }\end{array}$ \\
\hline E. coli O157:H7 & $10^{5}$ & 38.5 \\
Colicinogenic E. coli & $10^{5}$ & 61.5 \\
E. coli O157:H7 & $10^{5}$ & 3.6 \\
Colicinogenic E. coli & $10^{6}$ & 96.4 \\
E. coli O157:H7 & $10^{5}$ & 100.0 \\
Colicinogenic E. coli & $10^{5}$ & 100.0 \\
\hline
\end{tabular}

percentage of adhered bacteria is the result of the average of three independent experiments. The adherence of each strain separately was performed previously, and they showed the same rate of adherent bacteria to HEp-2 cells.

3.2. Adherence to Explants. On SMAC-Nal plates seeded from explants inoculated only with either E. coli O157:H7 or the colicinogenic strain, we observed both sorbitol-negative and sorbitol-positive colonies corresponding to the pathogenic and colicinogenic E. coli, respectively. On SMAC$\mathrm{Nal}$ plates, seeded from explants inoculated with colicinogenic E. coli and O157:H7, we obtained only sorbitolpositive colonies corresponding to the colicinogenic strain. The explants without inoculation did not show any colony on the agar plates.

When the explants inoculated with E. coli O157:H7 were analyzed immunohistochemically, we observed staining all along the epithelial edge which corresponds with the pathogenic bacteria attached to colonic epithelium (Figure 1(a)). In the explants inoculated only with the colicinogenic strain, it was not observed any staining (Figure 1(b)). On explants inoculated with a mixture of pathogenic and colicinogenic E. coli, we observed a significantly reduction of E. coli O157 adhered when compared with explant inoculated only with pathogenic bacteria (Figure 1(c)).

\section{Discussion}

An alternative to reduce the contamination of foods with STEC is the inhibition of proliferation of these pathogenic strains within the ruminant gastrointestinal tract which may be mediated by the use of probiotic bacteria [27]. These beneficial bacteria will fill the same ecological niche of the 
foodborne pathogens in the gastrointestinal tract, produce inhibitory substances, or modify the microenvironment of the intestinal tract in such a way that is inhibitory or deleterious to the target pathogens [28]. The use of colicinogenic E. coli to reduce E. coli $\mathrm{O} 157: \mathrm{H} 7$ in cattle is a promising method to control this foodborne pathogen. E. coli O157:H7 can itself be colicinogenic, which would make it resistant to certain colicins. However, the use of multiple colicinogenic strains might may reduce this possibility [29]. For that reason, we studied the ability of a colicinogenic E. coli strain with anti-O157 properties [26] to inhibit the attachment of E. coli O157:H7 to HEp-2 cells and to bovine colon which is the primary site of colonization. Adherence assays by using cell lines may constitute a simple, interesting, and welldimensioned model for conducting studies about the behavior of colicinogenic E. coli in the inhibition of the pathogenic strain colonization. There are studies that investigated the adherence of E. coli O157:H7 to cells and to organ explants ex vivo. In concordance with our findings, Dibb-Fuller et al. [30] showed that E. coli O157:H7 adhered to HEp-2 cells and with the highest number when compared with $E$. coli K12. In a study that tested the ability of lactobacilli to antagonize the biological effects of EHEC, Hugo et al. [31] could demonstrated, that a preincubation of monolayers with lactobacilli before inoculation with a clinical isolate of EHEC prevented detachment of eukaryotic cells and minimizes both $\mathrm{F}$-actin rearrangement and morphological alterations. In our study, we found that when HEp-2 cells were inoculated with colicinogenic E. coli and E. coli O157:H7, the adherence of these serotypes showed a marked reduction in comparison to when only pathogenic strain was inoculated. Girard et al. [32] demonstrated that the infection of an IVOC model from terminal ileon, terminal colon, and terminal rectum with $E$. coli $\mathrm{O} 157: \mathrm{H} 7$ resulted in a consistent pattern of colonization, characterized by scattered foci of intimately adherent bacteria in the terminal ileum and colon, whereas foci covering a larger surface of the epithelium were frequently observed in the terminal rectum and E. coli $\mathrm{O} 157$ were also found deep in the crypts in the terminal rectum. Phillips et al. [20] showed that O157:H7 caused attaching/effacing lesions on bovine mucosa, while Baehler and Moxley [19] inoculated bovine colon and rectum explants with E. coli $\mathrm{O} 157: \mathrm{H} 7$ and demonstrated that epithelial cells of inoculated explants developed A/E lesions at the bacterial attachment sites, providing evidence that the large intestinal mucosal epithelium may be a site of infection that contributes to carriage of E. coli O157:H7 in adult cattle. These results are consistent with ours, where we have shown that when the explants were inoculated with E. coli O157:H7, the strain was found attached to the epithelium of the colonic mucosa of the bovine species. Taking into account that colicinogenic E. coli was able to reduce the adherence of E. coli O157:H7 when both strains were inoculated on cell cultures and on bovine colonic explants, the impact of our study is that the colicinogenic strains could be used as a strategy to reduce cattle colonization with the pathogenic strain.

These are promising findings that allow thinking in the use of the colicinogenic E. coli as a potential probiotic strain and in the control of the colonization of bovine gastrointestinal tract with $E$. coli $\mathrm{O} 157: \mathrm{H} 7$. The colicinogenic strains may be used in the live animal on the farm before slaughter, thus reducing the entry of this pathogenic bacterium in the food chain. By this way, it may have the largest impact on improving beef safety and on the reduction of the possibilities of human infection.

\section{Acknowledgments}

The authors thank Dr. Marcelo E. Sanz for kindly providing antisera and María R. Ortíz for her technical assistance. A. I. Etcheverría is member of the Scientific Research Commission Prov. Buenos Aires (CIC). G. H. Arroyo is member of CONICET. This work was supported by FONCYT PICT 00/10068, CIC and SECAT-UNICEN.

\section{References}

[1] J. P. Nataro and J. B. Kaper, "Diarrheagenic Escherichia coli," Clinical Microbiology Reviews, vol. 11, no. 1, pp. 142-203, 1998.

[2] H. Karch, P. I. Tarr, and M. Bielaszewska, "Enterohaemorrhagic Escherichia coli in human medicine," International Journal of Medical Microbiology, vol. 295, no. 6-7, pp. 405-418, 2005.

[3] World Health Organization, "Enterohaemorrhagic Escherichia coli (EHEC)," http://www.who.int/mediacentre/factsheets/fs125/en/, 2005.

[4] P. I. Tarr, C. A. Gordon, and W. L. Chandler, "Shigatoxin-producing Escherichia coli and haemolytic uraemic syndrome," Lancet, vol. 365, no. 9464, pp. 1073-1086, 2005.

[5] G. L. Armstrong, J. Hollingsworth, and G. J. Morris Jr., "Emerging foodborne pathogens: Escherichia coli O157:H7 as a model of entry of a new pathogen into the food supply of the developed world," Epidemiologic Reviews, vol. 18, no. 1, pp. 29-51, 1996.

[6] M. Blanco, J. E. Blanco, J. Blanco et al., "Prevalence and characteristics of Escherichia coli serotype O157:H7 and other verotoxin-producing E. Coli in healthy cattle," Epidemiology and Infection, vol. 117, no. 2, pp. 251-257, 1996.

[7] T. E. Besser, D. D. Hancock, L. C. Pritchetf, E. M. McRae, D. H. Rice, and P. I. Tarr, "Duration of detection of fecal excretion of Escherichia coli O157:H7 in cattle," Journal of Infectious Diseases, vol. 175, no. 3, pp. 726-729, 1997.

[8] D. D. Hancock, T. E. Besser, D. H. Rice, D. E. Herriott, and P. I. Tarr, "A longitudinal study of Escherichia coli O157 in fourteen cattle herds," Epidemiology and Infection, vol. 118, no. 2, pp. 193-195, 1997.

[9] M. E. Sanz, M. R. Viñas, and A. E. Parma, "Prevalence of bovine verotoxin-producing Escherichia coli in Argentina," European Journal of Epidemiology, vol. 14, no. 4, pp. 399-403, 1998.

[10] A. E. Parma, M. E. Sanz, J. E. Blanco et al., "Virulence genotypes and serotypes of verotoxigenic Escherichia coli isolated from cattle and foods in Argentina: importance in public health," European Journal of Epidemiology, vol. 16, no. 8, pp. 757-762, 2000.

[11] I. Chinen, J. L. Otero, E. S. Miliwebsky et al., "Isolation and characterisation of Shiga toxin-producing Escherichia coli O157:H7 from calves in Argentina," Research in Veterinary Science, vol. 74, no. 3, pp. 283-286, 2003. 
[12] L. Meichtri, E. Miliwebsky, A. Gioffré et al., "Shiga toxinproducing Escherichia coli in healthy young beef steers from Argentina: prevalence and virulence properties," International Journal of Food Microbiology, vol. 96, no. 2, pp. 189-198, 2004.

[13] E. C. Mercado, A. Gioffré, S. M. Rodríguez et al., "NonO157 Shiga toxin-producing Escherichia coli isolated from diarrhoeic calves in Argentina," Journal of Veterinary Medicine Series B, vol. 51, no. 2, pp. 82-88, 2004.

[14] N. L. Padola, M. E. Sanz, J. E. Blanco et al., "Serotypes and virulence genes of bovine Shigatoxigenic Escherichia coli (STEC) isolated from a feedlot in Argentina," Veterinary Microbiology, vol. 100, no. 1-2, pp. 3-9, 2004.

[15] D. Fernández, E. Rodríguez, G. H. Arroyo, N. L. Padola, and A. E. Parma, "Seasonal variation of Shiga toxin-encoding genes $(s t x)$ and detection of E. coli O157 in dairy cattle from Argentina," Journal of Applied Microbiology, vol. 106, no. 4, pp. 1260-1267, 2009.

[16] L. J. Grauke, I. T. Kudva, J. W. Yoon, C. W. Hunt, C. J. Williams, and C. J. Hovde, "Gastrointestinal tract location of Escherichia coli O157:H7 in ruminants," Applied and Environmental Microbiology, vol. 68, no. 5, pp. 2269-2277, 2002.

[17] S. W. Naylor, C. Low, T. E. Besser et al., "Lymphoid follicledense mucosa at the terminal rectum is the principal site of colonization of enterohemorrhagic Escherichia coli O157:H7 in the bovine host," Infection and Immunity, vol. 71, no. 3, pp. 1505-1512, 2003.

[18] R. N. Cobbold, D. D. Hancock, D. H. Rice et al., "Rectoanal junction colonization of feedlot cattle by Escherichia coli O157:H7 and its association with supershedders and excretion dynamics," Applied and Environmental Microbiology, vol. 73, no. 5, pp. 1563-1568, 2007.

[19] A. A. Baehler and R. A. Moxley, "Escherichia coli O157:H7 induces attaching-effacing lesions in large intestinal mucosal explants from adult cattle," FEMS Microbiology Letters, vol. 185, no. 2, pp. 239-242, 2000.

[20] A. D. Phillips, S. Navabpour, S. Hicks, G. Dougan, T. Wallis, and G. Frankel, "Enterohaemorrhagic Escherichia coli O157:H7 target Peyer's patches in humans and cause attaching/effacing lesions in both human and bovine intestine," Gut, vol. 47, no. 3, pp. 377-381, 2000.

[21] T. R. Callaway, R. C. Anderson, K. J. Genovese et al., "Sodium chlorate supplementation reduces E. coli O157:H7 populations in cattle," Journal of Animal Science, vol. 80, no. 6, pp. 1683-1689, 2002.

[22] Center for Veterinary Medicine, "A proposed framework for evaluating and assuring the human safety of the microbial effects of antimicrobial new animal drugs intended for use in food-producing animals," FDA Center for Veterinary Medicine, http://www.who.int/mediacentre/ factsheets/fs125/en/, 2001. Accesed 20 April 2003.

[23] T. Zhao, M. P. Doyle, B. G. Harmon, C. A. Brown, P. O. E. Mueller, and A. H. Parks, "Reduction of carriage of enterohemorrhagic Escherichia coli O157:H7 in cattle by inoculation with probiotic bacteria," Journal of Clinical Microbiology, vol. 36, no. 3, pp. 641-647, 1998.

[24] T. Ohya, T. Marubashi, and H. Ito, "Significance of fecal volatile fatty acids in shedding of Escherichia coli $\mathrm{O} 157$ from calves: experimental infection and preliminary use of a probiotic product," Journal of Veterinary Medical Science, vol. 62, no. 11, pp. 1151-1155, 2000.

[25] M. M. Brashears, M. L. Galyean, G. H. Loneragan, J. E. Mann, and K. Killinger-Mann, "Prevalence of Escherichia coli
O157:H7 and performance by beef feedlot cattle given Lactobacillus direct-fed microbials," Journal of Food Protection, vol. 66, no. 5, pp. 748-754, 2003.

[26] A. I. Etcheverría, G. H. Arroyo, G. Perdigón, and A. E. Parma, "Escherichia coli with anti-O157:H7 activity isolated from bovine colon," Journal of Applied Microbiology, vol. 100, no. 2, pp. 384-389, 2006.

[27] M. P. Stevens, P. M. van Diemen, F. Dziva, P. W. Jones, and T. S. Wallis, "Options for the control of enterhaemorrhagic Escherichia coli in ruminants," Microbiology, vol. 148, no. 12, pp. 3767-3778, 2002.

[28] R. Fuller, "Probiotics in man and animals," Journal of Applied Bacteriology, vol. 66, no. 5, pp. 365-378, 1989.

[29] G. P. Schamberger and F. Diez-Gonzalez, "Assessment of resistance to colicinogenic Escherichia coli by E. coli O157:H7 strains," Journal of Applied Microbiology, vol. 98, no. 1, pp. 245-252, 2005.

[30] M. P. Dibb-Fuller, A. Best, D. A. Stagg, W. A. Cooley, and M. J. Woodward, "An in-vitro model for studying the interaction of Escherichia coli O157:H7 and other enteropathogens with bovine primary cell cultures," Journal of Medical Microbiology, vol. 50, no. 9, pp. 759-769, 2001.

[31] A. A. Hugo, E. Kakisu, G. L. de Antoni, and P. F. Pérez, "Lactobacilli antagonize biological effects of enterohaemorrhagic Escherichia coliin vitro," Letters in Applied Microbiology, vol. 46, no. 6, pp. 613-619, 2008.

[32] F. Girard, F. Dziva, P. van Diemen, A. D. Phillips, M. P. Stevens, and G. Frankel, "Adherence of enterohemorrhagic Escherichia coli $\mathrm{O} 157, \mathrm{O} 26$, and $\mathrm{O} 111$ strains to bovine intestinal explants ex vivo," Applied and Environmental Microbiology, vol. 73, no. 9, pp. 3084-3090, 2007. 

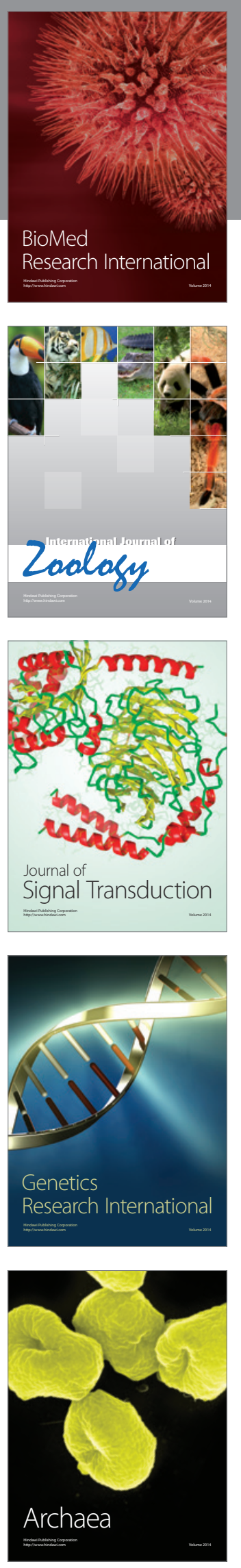
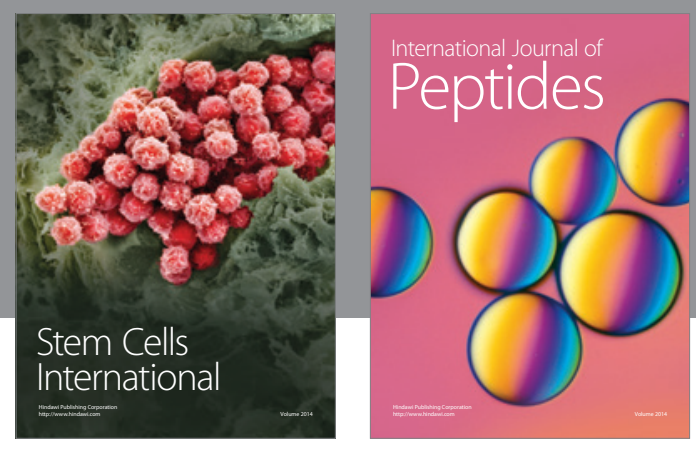

Submit your manuscripts at

http://www.hindawi.com
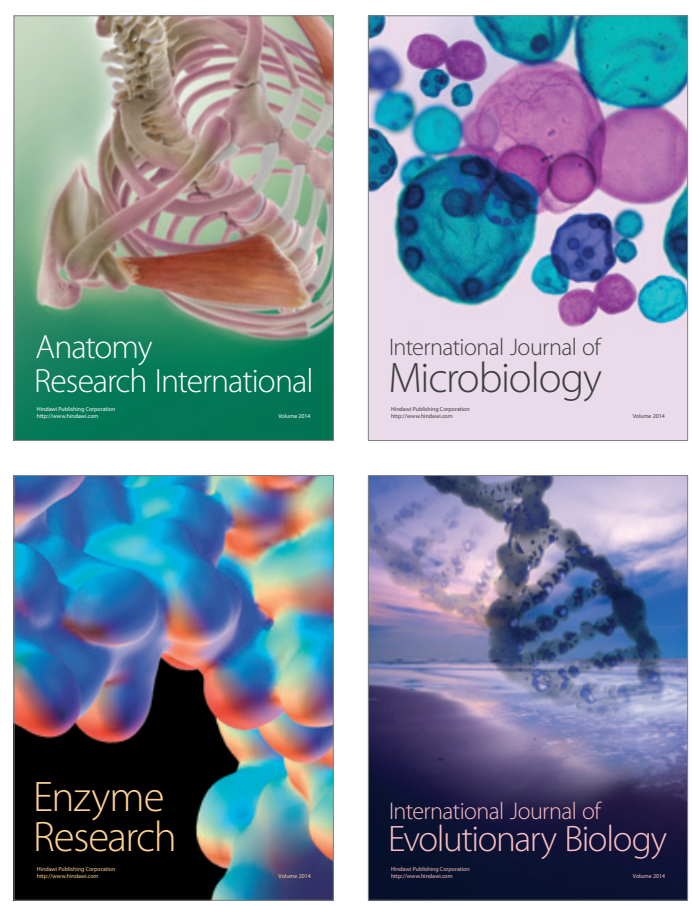
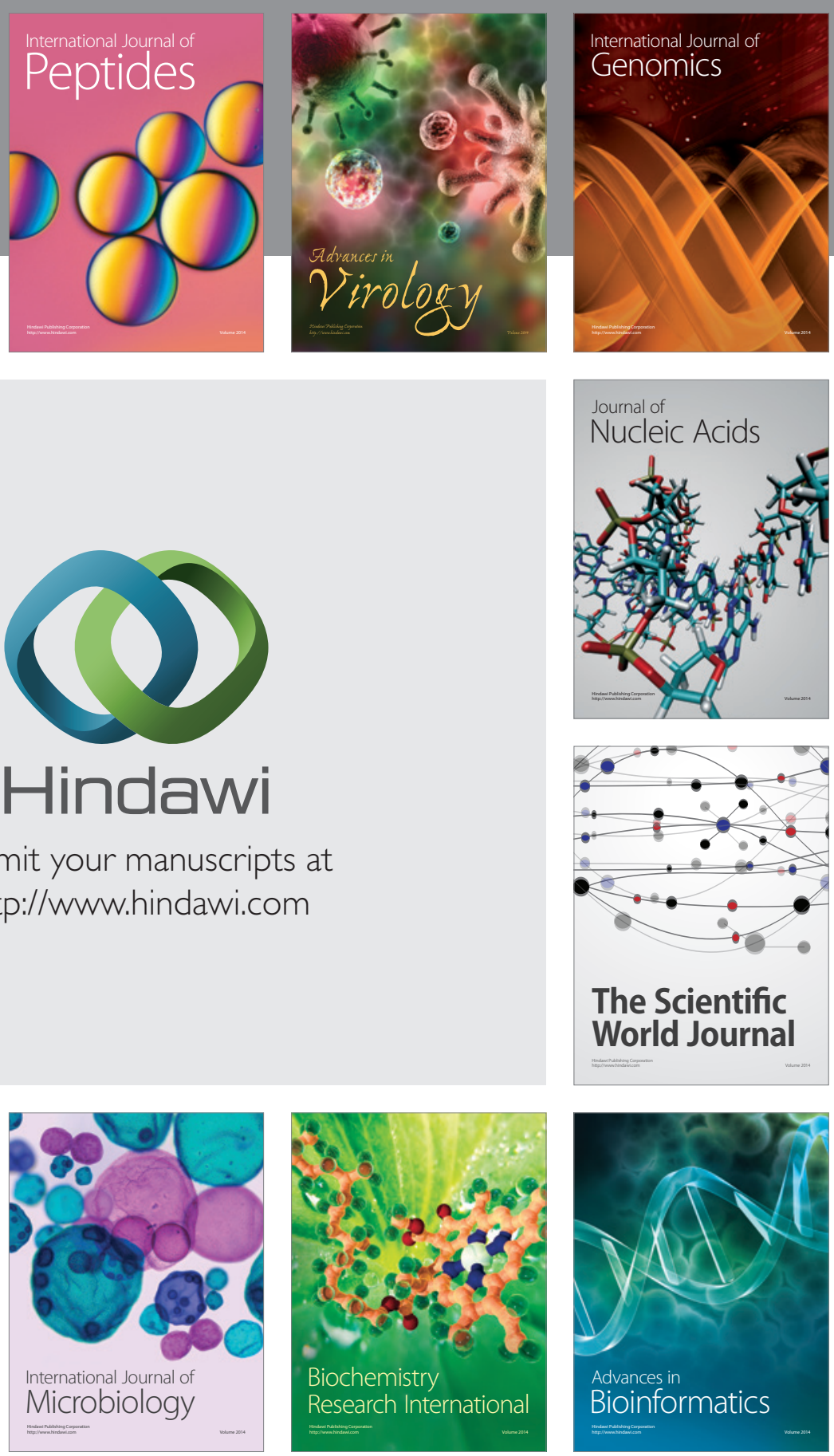

The Scientific World Journal
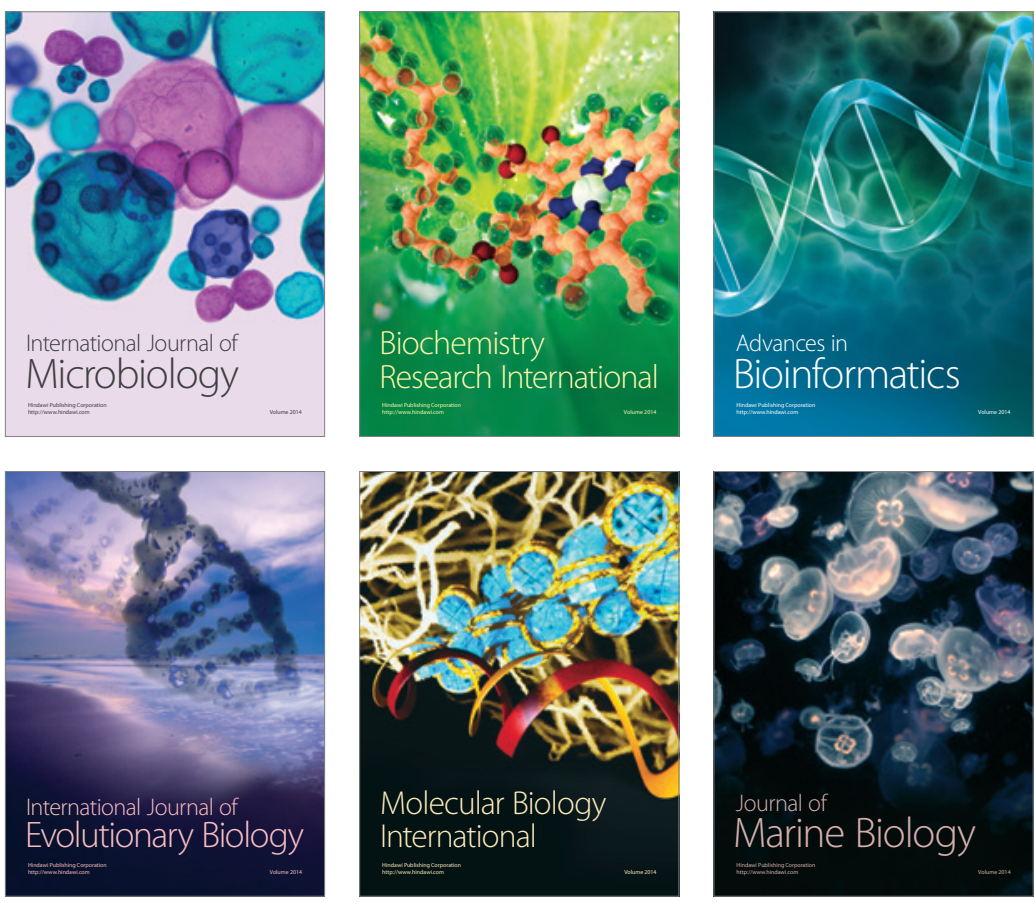